\title{
KANDUNGAN PROTEIN ROTI TAWAR DENGAN SUBTITUSI TEPUNG IKAN GABUS (Channa Striata)
}

\author{
Adriyani Adam ${ }^{1}$, Firdaus Syafii ${ }^{2}$ dan Saiful ${ }^{2}$ \\ ${ }^{1}$ Jurusan Gizi Poltekkes Kemenkes Makassar, Jln. Paccerakkang No. 14 Kota Makassar, Sulawesi Selatan \\ ${ }^{2}$ Jurusan Gizi Poltekkes Kemenkes Mamuju, Jln. Poros Mamuju Kalukku KM. 16 Tadui, Sulawesi Barat \\ Email : adriyani@poltekkes-mks.ac.id ${ }^{1}$
}

\begin{tabular}{l} 
Article Info \\
\hline Article history: \\
Received July $14^{\text {th }}, 2020$ \\
Revised August $21^{\text {th }}, 2020$ \\
Accepte September $25^{\text {th }}, 2020$
\end{tabular}

Keyword:

Channa Striata; Protein; White Bread.

\section{Kata Kunci :}

Ikan Gabus; Roti Tawar; Protein.

\begin{abstract}
Background : Malnutrition problem is still the top priority in Indonesia and one of focuses in the Medium Term Development Plan (RPJMN) for 2020-2024. Riskesdas 2018, show the percentage of nutritional status of stunting under five age in Indonesia 2018 was $25.7 \%$, in West Sulawesi Province was the second highest contributor for stunting children in Indonesia with prevalence 41.8\%. One of the preventive efforts that can be done is through the development of food products. In this study, the development of white bread with the substitution of Channa Striata fish flour was expected to enrich the nutritional content of bread, especially protein. In this study, using Channa Striata fish because it has a higher protein content than other foodstuffs known as sources of protein such as eggs, chicken and beef. Apart from protein, Channa Striata fish also has a high albumin content which can be used in wound healing. This aims of this study to determine the protein content of white bread with the substitution of Channa Striata fish meal by 5\% and $10 \%$
\end{abstract}

Methods : This type of research is an experimental study to determine the protein content in white bread with the substitution of Channa Striata fish meal by 5\% and 10\%. The analytical method used to assess protein content is the kjeidhal method, which is a simple method for determining total nitrogen in amino acids, proteins, and nitrogen-containing compounds. The test was carried out at Health Laboratory South Sulawesi.

Results : The results showed that the protein content of white bread with a substitution of 5\% was 9.03 grams, and a substitution of $10 \%$ was 10.38 grams.

Conclusion : The conclusion of this study was even more substitution of Channa Striata fish flour used, will increase protein content in the white bread.

\begin{tabular}{l} 
ABSTRAK \\
Latar Belakang : Masalah gizi buruk masih menjadi prioritas utama \\
di Indonesia dan menjadi salah satu fokus Rencana Pembangunan \\
Jangka Menengah (RPJMN) tahun 2020-2024. Hasil Riskesdas 2018, \\
menunjukkan persentase status gizi balita pendek di Indonesia tahun \\
2018 sebesar 25,7\%, sedangkan di Provinsi Sulawesi Barat \\
merupakan penyumbang balita stunting tertinggi kedua di Indonesia \\
dengan prevalensi 41,8\%. Salah satu upaya preventif yang dapat \\
dilakukan adalah melalui pengembangan produk pangan. Pada \\
penelitian ini pengembangan roti tawar dengan substitusi tepung \\
ikan gabus, diharapkan dapat memperkaya kandungan gizi pada roti \\
tawar khususnya protein. Dalam penelitian ini menggunakan ikan \\
\hline
\end{tabular}


gabus karena memiliki kandungan protein yang lebih tinggi dibandingkan bahan pangan lain yang dikenal sebagai sumber protein seperti telur, ayam dan daging sapi. Selain protein, ikan gabus juga memiliki kandungan albumin tinggi yang dapat digunakan dalam penyembuhan luka. Penelitian ini bertujuan untuk mengetahui kandungan protein roti tawar dengan substitusi tepung ikan gabus sebesar $5 \%$ dan $10 \%$.

Metode : Jenis penelitian ini adalah penelitian eksperiment untuk mengetahui kandungan protein pada roti tawar dengan substitusi tepung ikan gabus sebesar 5\% dan 10\%. Metode analisis yang digunakan untuk menilai kandungan protein adalah metode kjeidhal, yaitu metode sederhana untuk menentukan nitrogen total dalam asam amino, protein, dan senyawa yang mengandung nitrogen. Uji kandungan protein dilakukan di Balai Besar Laboratorium Kesehatan Propinsi Sulawesi Selatan.

Hasil : Hasil penelitian menunjukkan kandungan protein pada roti tawar dengan substitusi 5\% sebesar 9,03 gram dan substitusi 10\% sebesar 10,38 gram.

Kesimpulan : Kesimpulan penelitian ini adalah semakin banyak substitusi tepung ikan gabus yang digunakan, akan semakin meningkatkan kandungan protein pada roti tawar.

Copyright $($ C Jurnal Gizi Prima All rights reserved.

\section{PENDAHULUAN}

Protein merupakan salah satu makromolekul yang terdiri atas asam amino dengan ikatan peptida. Struktur penyusun asam amino dan pola ikatannya akan memberikan sifat yang berbeda-beda pada setiap protein. Untuk setiap protein, komposisi asam amino merupakan ciri khas dan unik. Protein yang disintesis memerlukan ketersediaan semua asam amino yang dibutuhkan pada titik sintesis dan terdapat 20 ada asam amino yang diperlukan untuk mensintesis protein tesebut. Asam amino dikelompokkan dalam asam amino esensial, non esensial dan asam amino netral. Dari 20 jenis asam amino terdapat 9 jenis asam amino yang dapat disintesis di dalam tubuh yaitu isoleusin, leusin, lisin, metionin, fenilalanin, treonin, triptofan dan valin. Protein berfungsi untuk menyediakan energi bagi tubuh, mengatur proses metabolism dan membantu proses pertumbuhan, sebagai zat pembangun, serta memelihara sel-sel jaringan tubuh.

Bahan pangan hewani merupakan sumber protein yang sangat baik, dalam jumlah maupun mutu. Salah satu bahan pangan hewani yang mengandung protein yang dibutuhkan oleh tubuh adalah ikan gabus. Penelitian yang dilakukan oleh Mustafa (2013) menemukan bahwa kandungan gizi yang terdapat dalam ikan gabus yaitu $\mathrm{Fe}, \mathrm{Ca}, \mathrm{Cu}$ dan Zn. Penelitian Suprayitno (2003) menjelaskan bahwa ikab gabus jenis c.striata mengandung albumin yang merupakan salah satu jenis protein yang sangat dibutuhkan oleh tubuh untuk metabolism setiap hari. Selain itu albumin yang terdapat pada ikan gabus sangat bermanfaat bagi mereka yang menderita hipoalbumin dan juga dibutuhkan pada pasien opreasi maupun luka bakar pada tahap penyembuhan luka.

Kondisi saat ini memperlihatkan kecenderungan masyarakat modern dalam memenuhi kebutuhan hidupnya dilakukan dengan secara instan. Sejalan dengan tingginnya aktivitas masyarakat tersebut dan kesadaran akan pentingnya makanan bergizi dan seimbang, sehingga mengkonsumsi roti adalah salah satu alternatif makanan untuk segala situasi dan kondisi khusunya pada saat waktu makan. Roti tawar merupakan salah satu produk pangan yang saat ini sudah sangat popular di masyarakat dengan berbagai macam jenis, bentuk dan rasa. Roti tawar juga biasa dikonsumsi sebagai pengganti nasi yang disukai oleh semua kalangan mulai dari anak-anak sampai dewasa. Roti tawar dengan dasar pembuatan dari tepung terigu, lemak, yeast, air dan garam serta ragi roti. Untuk kandungan gizi yang terdapat dalam roti tawar, diketahui lebih unggul dibanding yang terdapat dalam nasi dan mie. Dalam 100 gr roti tawar memberikan energi sebesar 248 kkal, sedangkan dalam 100 gr nasi memberikan energi sebesar $178 \mathrm{kkal}$ dan pada 100 gr mie hanya $86 \mathrm{kkal}$ energi (Astawan, 2014). 
Pemanfaatan tepung ikan gabus telah banyak dilakukan sebelumnya, pembuatan biskuit dengan subtitusi tepung ikan gabus yang menunjukkan bahwa dengan perlakuan subtitusi $30 \%$ biskuit tepung ikan gabus mengandung 16,1\% protein (Umar M, 2013), pembuatan bak mie dengan tepung ikan gabus dengan subtitusi $10 \%$ yang menunjukkan bahwa kadar protein sebanyak 10,8\% (Asmita, 2015).Diketahui bahwa bahan pangan sumber protein ikan gabus banyak ditemukan di perairan laut Indonesia, selain itu ikan gabus juga banyak ditemukan di sungai, danau maupun rawa. Dari sisi penampakan bentuk ikan gabus hampir menyerupai bentuk ikan lele. Sedangkan bentuk kepala ikan gabus hampir menyerupai ikan belut sehingga banyak masyarakat yang takut mengkomsumsi ikan gabus. Berdasarkan hal tersebut maka peneliti membuat inovasi dengan melakukan modifikasi roti tawar dengan subtitusi tepung ikan gabus sehingga diharapkan masyarakat dapat memperoleh manfaat protein dari ikan gabus yang disubtitusi pada produk roti tawar. Berdasarkan uraian tersebut maka tujuan dari penelitian ini adalah untuk mengetahui kandungan protein roti tawar dengan subtitusi tepung ikan gabus sebesar 5\% dan $10 \%$.

\section{METODE PENELITIAN}

Penelitian ini merupakan penelitian eksperimen yang dilaksanakan di Laboratorium Terpadu Poltekkes Kemenkes Mamuju. Penelitian ini merupakan penelitian dengan rancangan acak lengkap (RAL) satu faktor yaitu substitusi tepung ikan gabus yang terdiri dari 2 perlakuan yang memperoleh 4 unit percobaan. Pembuatan produk roti tawar dilaksanakan di Laboratorium terpadu sedangkan untuk uji kandungan protein dilakukan di Balai Besar Laboratorium Kesehatan Propinsi Sulawesi Selatan pada Maret 2019. Metode analisis kandungan protein roti tawar menggunakan Metode Kjeldahl yang merupakan salah satu metode sederhana untuk menganalisis kandungan protein pada bahan makanan melalui penetapan kadar nitrogen total yang terdapat pada asam amino, protein, dan senyawa yang mengandung nitrogen.

\section{HASIL DAN PEMBAHASAN PENELITIAN}

Penelitian ini dilakukan untuk mengetahui kandungan protein roti tawar dengan subtitusi tepung ikan gabus. Pada pembuatan roti tawar tepung ikan gabus terdapat dua subtitusi yaitu subtitusi tepung ikan gabus sebanyak 5\% dan 10\%. Adapun hasil peneltian tersebut adalah sebagai berikut.

Tabel 1. Hasil uji kandungan protein pada roti tawar dengan subtitusi tepung ikan gabus

\begin{tabular}{ccccc}
\hline No & Kandungan Protein & Pengujian Pertama & Pengujian Kedua & Rata-Rata \\
\hline 1 & $5 \%$ & $9.00 \mathrm{gr}$ & $9.06 \mathrm{gr}$ & $9.03 \mathrm{gr}$ \\
2 & $10 \%$ & $10.13 \mathrm{gr}$ & $10.64 \mathrm{gr}$ & $10.38 \mathrm{gr}$ \\
\hline
\end{tabular}

Sumber : Data Primer

Berdasarkan tabel di atas memperlihatkan bahwa kandungan protein pada setiap percobaan berbeda-beda, semakin banyak tepung ikan gabus yang digunakan maka semakin tinggi kandungan protein pada roti tawar tepung ikan gabus yang dibuat. Hal ini dapat dilihat dari rata-rata hasil subtitusi tepung ikan gabus, denga subtitusi 5\% memperlihatkan kandungan protein sebesar $9.03 \mathrm{gr}$ dan subtitusi $10 \%$ sebesar $10.385 \mathrm{gr}$.

Protein merupakan salah satu elemen struktural dan fungsional yang fundamental di dalam setiap sel dan akan mengalami ineraksi metabolic yang meluas. Interaksi metabolic yang tersebar luas ini berhubungan erat dengan metabolism energi dan nutrient lainnya. Protein adalah senyawa kimia yang terdapat dengan jumlah paling banyak setelah air. Fungsi utama protein bagi tubuh manusia adalah sebagai sumber asam amino esensial dan non esensial. Protein yang disintesis oleh tubuh sangat berperan dalam metabolism tubuh sebagai zat pembangun tubuh, zat pengatur dan mengganti sel-sel/jaringan tubuh yang rusak, serta berfungsi sebagai system imun untuk mempertahankan tubuh dari penyebab penyakit. Fungsi protein sebagai zat pembangun karena diketahui bahwa protein merupakan bahan pembentuk jaringan baru yang selalu terjadi dalam tubuh. Begitupula dengan fungsi protein sebagai sebagai zat pengatur dalam tubuh, karena protein merupakan bahan pembentuk enzim dan hormon, yang keduanya bekerja sebagai pengatur metabolisme dalam tubuh (Muchtadi, 2009 dalam Sri, 2014).

Ikan gabus adalah salah satu pangan hewani di peraian laut dari jenis ikan air tawar dari genus channa. Ikan gabus ini memiliki nilai ekonomis dan telah banyak banyak dimanfaatkan untuk dikonsumsi, walaupun sebagian masyarakat masih belum memahami kandungan gizi yang terdapat dalam ikan gabus tersebut. Dari tingkat konsumsi masyarakat terhadap ikan gabus masih rendah karena ikan gabus banyak ditemukan di 
rawa-rawa, danau dan sungai kecil sehingga masyarakat lebih memilih untuk mengkonsumsi ikan dari jenis lainnya. Sebagian besar masyarakat yang menyukai dan popular dengan ikan gabus, selain memiliki rasa yang enak dan gurih, tekstur daging yang tebal dan berwarna putih, serta tidak memiliki banyak tulang sehingga sangat tepat untuk dijadikan produk olahan yang akan tersedia sepanjang tahun. Kadar protein pada ikan gabus berkisar antara 17,28-18,12\%, dengan kadar protein tertinggi terdapat pada kelompok B $(18,12 \%)$ dimana kelompok B memiliki kisaran berat ikan gabus 801-1100 gram dan panjang 36,8-47,1 cm (Asikin AN, 2017).

Berdasarkan hasil penelitian diketahui bahwa kandungan protein pada setiap sampel berbeda, semakin banyak tepung ikan gabus yang digunakan maka semakin tinggi kandungan protein pada roti tawar yang dibuat, Jika dilihat dari rata-rata hasil subtitusi tepung ikan gabus 5\%, kandungan protein sebesar 9.03\% dan subtitusi $10 \%$, kandungan proteinnya10.38\%. Kadar protein roti tawar hasil subtitusi tepung ikan gabus 5\% menunjukkan bahwa dalam 100 gram produk ini mengandung 9.03 gram protein sama halnya dengan hasil kadar protein pada roti tawar subtitusi tepung ikan gabus $10 \%$ menunjukkan bahwa dalam 100 gram produk ini mengandung 10.38 gram protein.

Pembuatan roti tawar tepung ikan gabus dengan bahan utama yang digunakan adalah tepung terigu dan tepung ikan gabus. Tepung terigu merupakan ekstraksi dari tepung gandum yang tersusun oleh 67-70\% karbohidrat. Gluten merupakan protein utama dalam tepung terigu yang terdiri dari gliadin $20-25 \%$ dan glutenin 35-40\% (Fitasari, 2009). Standar Nasional Indonesia menetapkan bahwa dalam 100 gram tepung terigu mengandung kadar protein sebanyak 7 gram (SNI, 2009). Tepung ikan gabus merupakan daging ikan gabus yang dikeringkan dan dihaluskan. Rata-rata kadar protein terlarut tepung ikan gabus adalah 10,88\% (Mardiana, 2014). Roti tawar sendiri merupakan roti yang tidak ditambahkan rasa atau isi apapun sehingga rasanya tawar. Kadar protein pada roti tawar dalam 100 gram terdapat 8 gram kadar protein (Shabrina, 2017).

Tepung terigu yang merupakan bahan utama dalam pembuatan roti tawar memiliki minimal kadar protein sebanyak 7\% (SNI,2009), kemudian tepung ikan gabus dalam memiliki kadar protein sebesar $10.88 \%$ (Mardiana, 2014), selanjutnya kadar protein pada roti tawar sendiri memiliki kadar protein $8 \%$ (Shabrina, 2017), sementara hasil penelitian ini menunjukkan bahwa roti tawar hasil subtitusi ikan gabus 5\% menghasilkan kadar protein sebesar $9.03 \%$ dan subtitusi $10 \%$ menghasilkan kadar protein sebesar $10.38 \%$. Berdasarkan data hasil penelitian menunjukkan bahwa ada kenaikan jumlah protein pada roti tawar yang tersubtitusi tepung ikan gabus. Pada roti tawar subtitusi tepung ikan gabus 5\% terdapat kenaikan jumlah protein sebesar $1,03 \%$, sedangkan pada roti tawar subtitusi $10 \%$ mengalami peningkatan kadar protein sabesar 2,38\%. Hal ini sejalan dengan Jatmika (2013) tepung ikan yang berasal dari ikan segar memiliki kandungan protein tinggi yang akan mempengaruhi kandungan protein pada produk.

Roti tawar pada umumnya memiliki kandungan protein yang minim atau sedikit. Dengan penambahan subtitusi tepung ikan gabus diharapkan mampu menambah atau meningkatkan kadar protein pada produk roti tawar. Meskipun tidak terjadi peningkatan yang drastis, namun pada penelitian ini menunjukkan terjadi peningkatan kadar protein seperti yang diharapkan.

\section{KESIMPULAN}

Berdasarkan analisis kandungan protein roti tawar dengan subtitusi tepung ikan gabus, memperlihatkan terjadinya peningkatan kandungan protein dengan subtitusi $5 \%$ dan $10 \%$. Semakin besar penambahan tepung ikan gabus maka akan semakin meningkatkan kandungan protein pada roti tawar.

\section{SARAN}

Roti tawar dengan subtitusi tepung ikan gabus dapar dapat direkomindasikan sebagai makanan tambahan baik bagi anak balita maupun ibu hamil. Dalam upaya pencegahan stunting, khususnya pada daerah-daerah dengan akses pangan hewani yang sangat rendah, dapat memanfaatkan roti tawar ikan gabus sebagai salah satu alternatif pangan dalam memenuhi kebutuhan gizi khususnya kebutuhan akan protein, sehingga dapat menurunkan prevalensi kejadian masalah gizi di masyarakat.

\section{DAFTAR PUSTAKA}

Ana Annisa L.F dan Diana Nur Afifah (2015). Kadar Protein, Nilai Cerna Protein In Vitro Dan Tingkat Kesukaan Kue Kering Komplementasi Tepung Jagung Dan Tepung Kacang Merah Sebagai Makanan Tambahan Anak Gizi Kurang. Journal Of Nutrition College, Volume 4 (2) 
Asikin AN (2017). Edible portion dan kandungan kimia ikan gabus hasil budidaya kolam di Kabupaten kutai kartanegara, Kalimantan Timur. Zira'ah, Volume 42 No 3.

Badan penelitian dan pengembangan. (2018). Hasil riskesdas 2018. Kementerian Kesehatan RI

Fatmawati dan Mardiana. 2014. Tepung ikan gabus sebagai sumber protein. Volume 23 nomor 3.

Irianti Sri. 2014. Inovasi bakso dari ikan gabus dengan subtitusi daun kelor dan wortel. Volume 25 nomor 5.

Nurilmala Mala. (2017). Karakteristik protein ikan gabus yang berpotensi sebagai anthihiperglikemik. Journal.ipb.ac.id. Volume 20 No 2.

Mardiana dan Fatmawati.(2014). Analisa tepung ikan gabus sebagai sumber protein. Volume 3 No 1. Muh. Asfar, Abu Bakar Tawali, dan Meta Mahendradatta. (2014). Potensi Ikan Gabus (Channa Striata) sebagai Sumber Makanan Kesehatan-Review. Posiding Seminar Nasional Teknologi Industri II 2014 Rijal, Muhammad. 2016. Prospek Limbah Ikan di Maluku.--Ed.1, Cet. 1-- Yogyakarta: Deepublish.

Shabrina Nadhila. (2017). Pengaruh subtitusi tepung terigu dengan tepung kacang koro prdang dan lama fermentasi terhadap karakteristik roti tawar. Skripsi. Program studi tekhnologi pangan. Universitas Pasundan Bandung.

Tommy Marcelino Ganthoe. (2012). Formulasi Cookies Fungsional Berbasis Tepung Ikan Gabus (C Umar Musdalifah. (2013). Studi pembuatan biskuit dengan subtitusi tepung ikan gabus. Fakultas Pertanian. Universitas Hasanuddin.

Yuliani dkk. 2014. Karakteristik kerupuk ikan dengan subtitusi tepung ikan gabus sebagai fortifikasi kalsium. Volume 21 nomor 2 